\title{
Enlightenments and Challenges: English Translation of Chinese Classics in College English Teaching and Learning for Non-English Major Students
}

\author{
Chen Xiaoqing \\ Foreign Language Department \\ Qingdao Agricultural University \\ Qingdao, China
}

\begin{abstract}
With further development of globalization and the increasingly close economic and cultural exchanges between China and foreign countries, there are new higher requirements for college English teaching and learning in China. One of those is an urgent need to cultivate college English learners' sufficient intercultural communicative competence. However, the very existence of Chinese Culture Aphasia makes it hard to meet such demand. Even if some teachers have consciously involved culture teaching in their classes, a serious imbalance between western culture teaching and the students' home culture remains there. To eliminate the influence of this aphasia, some researchers and experts propose incorporating English translation of Chinese classics into college English teaching. Based on this, this paper presents not only how to integrate English translation of Chinese classics in college English teaching for non-English major students, but also sharing some of its enlightenments as well as exploring some challenges in teaching practice.
\end{abstract}

Keywords-college English teaching and learning, culture teaching, English translation of Chinese classics, non-English major students

\section{INTRODUCTION}

College English as an indispensable part of higher education helps the non-English major students to attain basic language competences. Particularly, with the further development of globalization and the increasingly close economic and cultural exchanges between China and foreign countries, there are new higher requirements for college English teaching and learning in China, that is, to cultivate college English learner's sufficient intercultural communicative competence.[5] Since such intercultural communicative competence is an equal and two-pronged exchange of different cultures, it undoubtedly means not only a mastery of western culture but also the traditional Chinese culture.

However, according to many researches there is much left to be desired to meet this urgent demand. In most college English classrooms in China, teachers and educators either still follow a linguistic knowledge-centered teaching mode or lay too much emphasis on western culture learning while neglecting the Chinese culture. The Chinese native culture related materials still can rarely be seen in the compilation of college English textbooks. Most students have great difficulties to introduce Chinese culture to foreigners in their cross-cultural communications.[4] The fact that there is an existence of Chinese Culture Aphasia has been widely acknowledged and has attracted increasing attention of many educators and scholars.

In confronting such serious and worrying Chinese Culture Aphasia in college English teaching and learning, some researchers and experts propose that incorporating English translation of Chinese classics into college English teaching is beyond any doubt the most effective way to eliminate the influence of this Aphasia. Based on this, this paper is trying to explore some of the challenges in integrating the English translations of Chinese classics into English teaching for nonEnglish major students along with sharing some of its enlightenments in this teaching process.

\section{ENGLish TRANSLATION OF CHINESE Classics IN COLLEGE ENGLISH TEACHING AND LEARNING}

Chinese cultural classics are the very essence of the profound and precious Chinese culture, which embody not only the great wisdom and creativity of Chinese nation but also the enchanting charm of Chinese civilization. With the development of globalization and the increasingly frequent cultural exchanges, the English translation of Chinese classics is of the paramount importance to promote the popularization of Chinese culture in the world and it is helpful to develop the diversity of the world culture.

Integrating Chinese cultural classis into college English teaching is to improve the native culture awareness of college students and their intercultural communicative competence.[1] The seminal text of Taoist philosophy---Tao Te Ching, Chuang-Tzu, Confucian classics represented by Four Books, Five Classics and The Analects, and the most precious and enchanting classical Chinese poetry like Tang Poems, etc., are the concentration of Chinese nations' core values and great spiritual quality. They display the uniqueness of Chinese culture. 
Undoubtedly, they are all of great significance in not only arousing the students' interests in learning English but also maintaining their national culture identity as well as improving their intercultural communicative competence. And this has been proved in an empirical teaching program carried out in Qingdao Agricultural University. In the teaching practice in four non-English major classes for two years, statistics show that when the teacher determines and consciously incorporates the English translation of those Chinese classics into English teaching, over $87 \%$ of the students announce that they become more and more interested in English learning. Their national cultural awareness and intercultural communicative competence has been largely improved.

In the two years of culture teaching for non-English major students, many English translations of Chinese classics are incorporated in college English teaching. They are presented in various kinds of class activities. Tao Te Ching, is a good example to be integrated into college English teaching when the students are dealing with the theme---The Road to Success in Unit 3, New Century College English II. When referring to the key personalities that are critical for a person to achieve success, the trait of perseverance is never to be missed by students. Then, the teacher naturally introduce the sentence in Tao Te Ching, that is, “天下之至柔,驰骋天下之至坚”, instructing the students to realize the profound thought of Lao $\mathrm{Zi}$ and ensuring that they can fully understand Lao Zi insists a sage should be like water, being smooth, quiet, and continuous. Although water is the softest thing, it never recoils from dangers and difficulties. It is with such resolution and persistence that dropping water can wear stone and small streams can finally take the shape of a river and ocean. Simultaneously, the students are going to learn some other special connotation of water in Chinese culture, such as water is the great source of life and it is the symbol of breeding growing and energy. Combining Chinese culture can greatly inspire the students in their English learning and help them to express themselves better in cross-culture communications.

Confucianism which stands for the quintessence of Chinese culture is another part that should never be neglected in culture teaching in college English. The Analects, a collection of records of sayings, conversations and observations given by Confucius and his disciples, has a very rich cultural connotation and denotes Confucianism well.[7] Many of the Confucian ethical thinking can be implement flexibly in English teaching. For instance, when it comes to the theme of Friendship in the third unit in New Century College English III, the teacher can naturally introduce the classical views of friendship in Chinese culture by mentioning what Confucius said, "Three kinds of friends will do one good...Upright friends, trustworthy friends, and well-informed friends will do one good.” (孔子曰: “益者三友……友直, 有谅, 友多闻, 益 矣。” ) Moreover, some other widely spread historic stories and anecdotes of the ancient sages such as how Yu Boya and Zhong Ziqi became bosom friends can also be involved in the design of the class activities.

Additionally, as a shining pearl in the spire of classical Chinese literature art, the Tang Poems have been highly appreciated both at home and abroad. This makes it difficult to overestimate its value in cultivating English learners' intercultural communicative competence. The appreciation and comparison of both Chinese and western poetry in college English teaching is a chance to not only narrow down the gaps between the East and the West but also build up the students' self-confidence in Chinese culture as well as their national culture awareness.

Incorporating the English translation of Chinese classics such as those mentioned above paves the way for striking a balance between the western and Chinese culture in college English classes. Nevertheless, in a multimedia teaching environment, how to make the best out of internet and Mlearning to attain the ideals of English teaching and learning has become another subject worthy of further study. There are still a number of challenges and problems in front.

\section{CHALLENGES TO INCORPORATE ENGLISH TRANSLATION OF CHINESE ClASSICS INTO ENGLISH TEACHING FOR NON- ENGLISH MAJOR STUDENTS IN A MULTIMEDIA TEACHING ENVIRONMENT}

In a multimedia teaching environment, it is convenient and flexible to incorporate the English translation of Chinese classics into English teaching. Computer assisted language teaching and learning make it much easier to enrich the teaching content and class activities by adding Chinese culture. However, there are some other challenges and difficulties for both teachers and students to deal with in practice.

First and foremost, for the lack of a reasonable design of cultural teaching syllabus and a new revision of curriculum, the teacher can hardly implement Chinese culture teaching in a systematic and effective way especially when there is a serious imbalance in cultural content in the compilation of textbooks. Admittedly, it is high time that the college English teachers changed the traditional linguistic knowledge-centered teaching mode, revised their understanding of cultural teaching, improved their own intercultural competence, rearranged and stroke a balance between Chinese culture and western culture in their courses.[6] All of these countermeasures are in the hope that the teachers can eventually guide their students to establish a correct and healthy cultural awareness and improve their intercultural communicative competence.

Secondly, under the influence of exam-oriented education in China, it takes time and efforts to change the students' viewpoint of language study and culture study. At present, even though incorporating the English translation of Chinese classics has proved to be very effective to promote students' intrinsic interest in learning English and Chinese culture, such culture imbalance is not going to be changed fundamentally if Chinese culture is not integrated in all kinds of English tests. Simultaneously, the students' poor self-learning ability is still one of the most vexing problems that hinges on the cultivation of their intercultural communicative competence.[3] For nonEnglish major students it is particularly difficult to expressing the Chinese culture in proper English when they haven't established a correct cultural awareness and cultural identity.

Last but far from the least, in a multimedia teaching environment, both teachers and students should take advantage 
of multimedia devices and various kinds of mobile terminals to improve their efficiencies. Then the question rises, how to find the most authoritative materials and reliable resources for students, and how to inspire and supervise them after class if the teachers are to encourage them to learn Chinese culture based on M-learning? In the two years of teaching practice, it is obvious that the more carefully the teacher selects materials for students to carry on in their M-learning, the better the teaching effect is. For instance, the teacher should try to search online or in the library first trying to find appropriate materials and then examine such English translations carefully before involving them into the design of teaching activities deliberately. Evidences also bears out the idea that students learn Chinese culture best in small groups within which it is both cooperative and competitive. By making use of new technology such as to follow some official accounts of Chinese culture in the Wechat or follow some famous micro blogs, students' learning motivations and interest are highly improved. They became fascinated by the English translation of many Chinese classics, especially the differences in various versions of translation and the cultural distinctions between the East and the West.

\section{CONCLUSION}

Apparently, in confronting the phenomenon of Chinese Culture Aphasia, to incorporate the English translation of Chinese classics into college English teaching and learning becomes urgent and indispensable in its critical role to help the students maintain their national and cultural identity, enhance their self-confidence in their national culture as well as improving their intercultural communicative competence. And in the teaching practice, both teacher and students need to devise a more effective way to make the best use of new teaching pedagogy and resources to implement the English translation of Chinese classics in their college English. Only in this way can they really achieve a balance between the Chinese and the western culture, and eventually cultivate their intercultural communicative competence.

\section{REFERENCES}

[1] Lafayette, R. C. Culture in second language learning and teaching: Anthropology Revisited [A]. In Lange, D. L. et al. CARLA Working Paper(11)[C]. 1998. 109-124.

[2] Lange, D. L. Implications of Theory and Research for the Development of Principles for Teaching and Learning Culture in Second Language Classrooms[M]. In R. M. Paige (ed.), 1999.

[3] Li Jiapu. A Case Study on Chinese Culture Aphasia of English-Majors [MA] Southwest University, 2011.

[4] Moran P. R. Teaching Culture: Perspectives in Practice [M]. Beijing: Foreign Language Teaching and Research Press, 2004.

[5] Wrights, S. Language Policy and Language Planning: From Nationalism to Globalization[M]. New York: Palgrave Macmillan, 2004.

[6] Yang Meirong. An Empirical Study on the Current Situation of "Chinese Culture Aphasia” in College English Teaching [MA]. Northwest Normal University, 2013

[7] Zhao Changjiang. A Study of English Translation of Chinese Cultural Classics in the 19th Century[MA]. Nankai University, 2014 